\title{
Stages of ICT implementation on buses and at major bus terminal in Indonesia for sustainable transportation
}

\author{
Anastasia Caroline Sutandi ${ }^{1, *}$ \\ ${ }^{1}$ Department of Civil Engineering, Universitas Katolik Parahyangan, Bandung, Indonesia
}

\begin{abstract}
Information and Communication Technology (ICT) on buses and at major bus terminal in large cities in Indonesia is needed for sustainable transportation. Based on the existing condition of buses and major bus terminals, ICT implementation cannot be completed at one go, but needs to be done in different stages. The aims of this study are identification of existing ICT implementation, to determine the necessity and priority of ICT implementation based on passengers' needs and to provide stages of ICT implementation on buses and at major bus terminals in Indonesia for the purpose of sustainable transportation. Case studies are carried on Trans-Sarbagita buses and at Mengwi major bus terminal in Denpasar, Bali and on Surabaya-Yogyakarta buses and at Purabaya major bus terminal in Surabaya, Indonesia. Five hundred and sixty-six passengers and the terminal authority are involved in this study. Data collecting method is questionnaire and interview. Important performance analysis is used in analysis. Results indicated that the stages are: 1) maintenance of existing ICT daily operations, i.e. CCTV and online-ticketing, 2) dissemination of existing and future ICT facilities to the society, 3) effort to implement ICT needed by passengers, 4) effort to implement ICT based on passengers' priority, and 5) implementation of other advanced ICT in the future with financial support and the firm effort of local government, national government and industry, consistently and continuously.
\end{abstract}

\section{Introduction}

Sustainable transportation can be defined in many concepts. One of the common concepts of sustainable transportation is transportation that uses renewable resources, has a low impact of pollution emission to the environment, maximizes the use of Information and Communication Technology (ICT), and does not burden future generations. The uses of ICT in transportation can reduce traffic congestion and increase safety, mobility, comfort, convenience, and service quality and can lead transportation towards sustainable transportation [1-9].

\footnotetext{
* Corresponding author: caroline@unpar.ac.id
} 
Since the existing condition of ICT implementation on buses and major bus terminals in large cities in Indonesia is still at the beginning level, ICT implementation, therefore, needs stages to be implemented. The aims of this study are identification of existing ICT implementation on buses and at major bus terminals, to determine the necessary and priority ICT implementation based on passengers' needs, to provide stages of ICT implementation on buses and at major bus terminals in Indonesia towards sustainable transportation. The stages are strategic to implement ICT in practice based on existing condition so that they can be applied as quickly as possible. Results of this study can be beneficial to be implemented on other buses and other bus terminals in large cities in developing countries with a similar existing condition.

\section{ICT on buses and at bus terminals}

\subsection{ICT implementation on buses and at bus terminals}

ICT as advanced technology in transportation is a part of an intelligent transportation system (ITS). ICT in this study is especially ICT that is implemented on buses and at major bus terminals in large cities. Such implementation will support the bus terminal authority to achieve a short operational time as well as potential cost saving and, therefore, increase daily bus operations and managed efficiently and effectively in practice. ICT implementation can be by bus e-ticketing, a bus priority system, and availability of parking space facility $[1-4,6,10]$.

Using real field data collection, improvement of terminal operation surveillance and real-time passenger information regarding name and number of the bus, bus route, bus timetable, the bus location system, a bus delay time can be provided accurately in real time. Real-time passenger information can be distributed through bus terminal website, mobile application, television station, radio station, and also in the bus terminal and at the bus station $[11,12]$.

\subsection{Existing condition of ICT implementation on buses and at major bus terminals in Indonesia}

A primary bus terminal is an important part of the transport system that serves bus operations daily. Unfortunately, this important element in large cities in Indonesia is only supported by ICT at the beginning level. The existing condition shows that the only basic ICT that has been implemented in major bus terminals is bus e-ticketing on a few bus routes between large cities.

Based on the results of interviews with the terminal authority, the existing basic ICT implementation at major bus terminals is CCTV in the terminal and e-ticketing. Furthermore, the limited ability of bus terminal officers and limited financial support to implement ICT is a major challenge.

\section{Research methodology}

The research methodology of ICT implementation on buses and at major bus terminals in Indonesia on sustainable transportation is presented in Fig. 1. A questionnaire to 566 passengers as respondents and interviews with the major bus terminal authorities are used in field data collecting.

The questionnaire is based on the Ministry of Transportation of Republic of Indonesia regulations and the average value of passengers' answers using a Likert scale regarding the 
implementation of bus e-ticket service and is presented in Table $1[13,14,15]$. The questionnaire also based on Ministry of Transportation of Republic of Indonesia regulations and the average value of passengers' answers using Likert scale regarding the implementation of ICT at major bus terminals is presented in Table $2[13,14,15]$. The Likert scale value is between 1 (not greatly needed or not greatly prioritized) up to 5 (greatly needed or greatly prioritized) based on passengers' opinions as bus and terminal users [16].

Moreover, the Important Performance Analysis method is used in an analysis to provide the value of a level of necessity and value of a level of priority of the bus e-ticket service and also the value of a level of necessity and value of a level of priority of ICT implementation at major bus terminals [17]. Value of Important Performance Analysis is described in Cartesian Diagram and presented in Fig. 1 and 2.

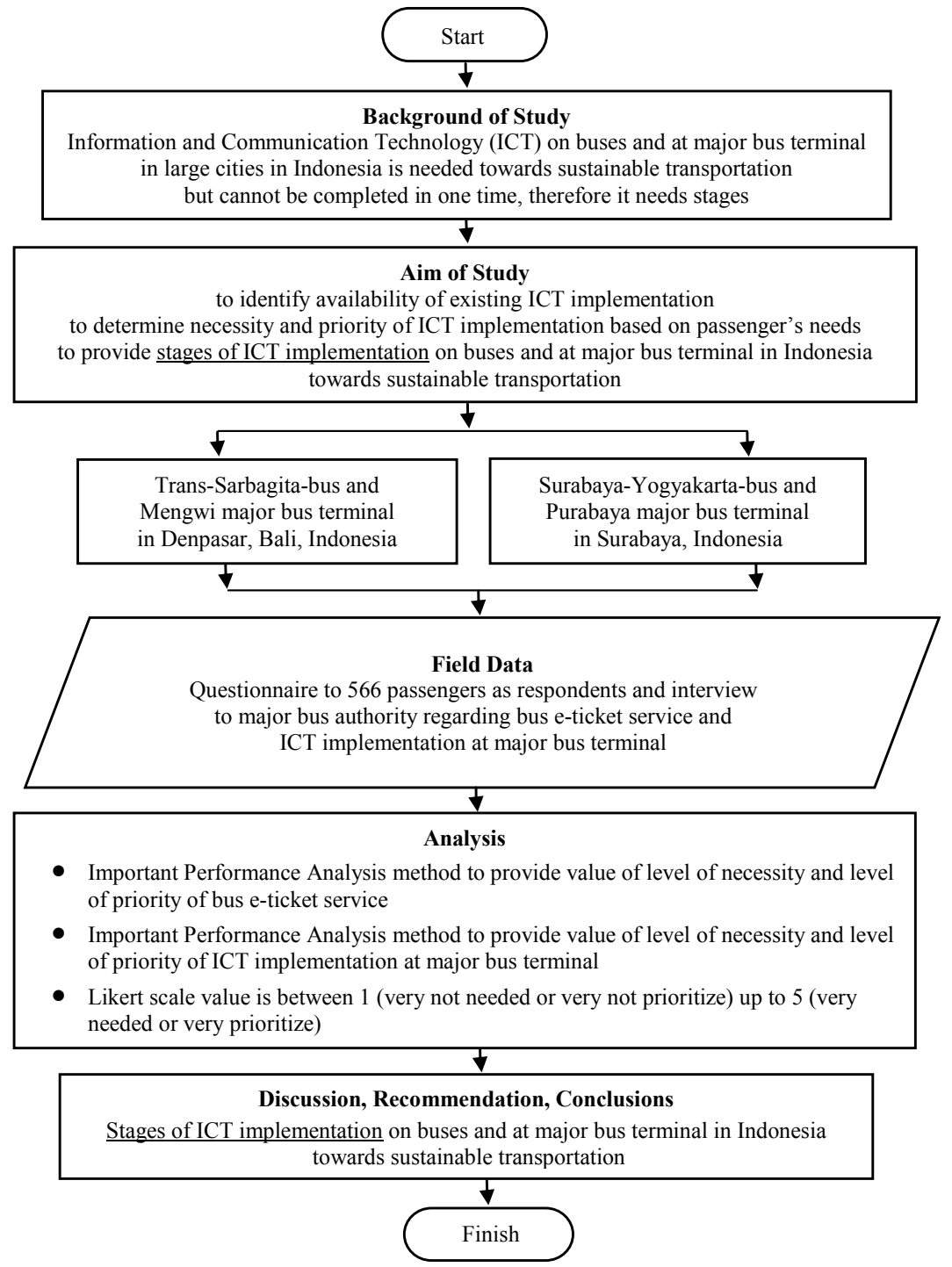

Fig.1. Methodology of research of stages of ICT Implementation on buses and at major bus terminals in indonesia towards sustainable transportation. 


\section{Results and discussion}

\subsection{Field data regarding bus e-tickets and ICT implementation}

The first primary data are from a questionnaire to 566 passengers as respondents on TransSarbagita buses in Denpasar, Bali, and on Surabaya-Yogyakarta buses in Surabaya, East Java regarding bus e-ticket service necessity and priority by surveyors. The questionnaire and average value of respondents' answers are presented in Table 1.

Table 1. Level of necessity and level of priority of bus e-ticket service.

\begin{tabular}{|c|c|c|c|c|c|}
\hline \multirow{2}{*}{ Component } & \multirow{2}{*}{ E-ticket questionnaire } & \multicolumn{2}{|c|}{$\begin{array}{c}\text { Trans-Sarbagita Buses } \\
\text { Denpasar, Bali }\end{array}$} & \multicolumn{2}{|c|}{$\begin{array}{c}\text { Surabaya-Yogyakarta } \\
\text { Buses, Surabaya, East } \\
\text { Java }\end{array}$} \\
\hline & & $\begin{array}{l}\text { Level of } \\
\text { Necessity }\end{array}$ & $\begin{array}{l}\text { Level of } \\
\text { Priority }\end{array}$ & $\begin{array}{l}\text { Level of } \\
\text { Necessity }\end{array}$ & $\begin{array}{l}\text { Level of } \\
\text { Priority }\end{array}$ \\
\hline $\mathrm{P}_{1}$ & $\begin{array}{l}\text { Ease of getting bus e-ticket } \\
\text { information service }\end{array}$ & 3.99 & 4.01 & 4.16 & 3.65 \\
\hline $\mathrm{P}_{2}$ & $\begin{array}{l}\text { Availability of bus schedule while } \\
\text { buying a bus e-ticket }\end{array}$ & 4.04 & 4.00 & 3.69 & 3.68 \\
\hline $\mathrm{P}_{3}$ & $\begin{array}{l}\text { Availability of bus route while } \\
\text { buying a bus e-ticket }\end{array}$ & 4.15 & 4.08 & 3.89 & 3.61 \\
\hline $\mathrm{P}_{4}$ & $\begin{array}{l}\text { Ease of getting bus e-ticket service } \\
\text { access }\end{array}$ & 4.06 & 3.92 & 3.86 & 3.66 \\
\hline $\mathrm{P}_{5}$ & $\begin{array}{c}\text { Consistency of bus e-ticket service } \\
\text { time }\end{array}$ & 4.05 & 3.92 & 3.81 & 3.69 \\
\hline $\mathrm{P}_{6}$ & Cleanliness of bus e-ticket counter & 3.98 & 3.78 & 3.82 & 3.61 \\
\hline $\mathrm{P}_{7}$ & Security of bus e-ticket counter & 4.11 & 3.96 & 3.79 & 3.65 \\
\hline $\mathrm{P}_{8}$ & $\begin{array}{c}\text { Availability of bus e-ticket service at } \\
\text { bus ticket counter }\end{array}$ & 3.77 & 3.76 & 3.84 & 3.76 \\
\hline $\mathrm{P}_{9}$ & Bus e-ticket selling service time & 3.86 & 3.80 & 3.88 & 3.79 \\
\hline $\mathrm{P}_{10}$ & Affordability of bus e-ticket & 4.13 & 4.04 & 3.89 & 3.83 \\
\hline $\mathrm{P}_{11}$ & Ease of bus e-ticket top up & 4.04 & 3.87 & 3.85 & 3.81 \\
\hline $\mathrm{P}_{12}$ & Servicing of bus e-ticket officer & 3.96 & 3.79 & 3.78 & 3.69 \\
\hline $\mathrm{P}_{13}$ & Hospitality of bus e-ticket officer & 3.87 & 3.68 & 3.80 & 3.65 \\
\hline $\mathrm{P}_{14}$ & Officer knowledge of bus e-ticket & 4.00 & 3.85 & 3.84 & 3.69 \\
\hline $\mathrm{P}_{15}$ & $\begin{array}{c}\text { Ease of bus e-ticket tap in and tap } \\
\text { out }\end{array}$ & 3.98 & 3.79 & 3.76 & 3.75 \\
\hline $\mathrm{P}_{16}$ & $\begin{array}{l}\text { Convenience of passengers while } \\
\text { queued to buy bus e-ticket }\end{array}$ & 4.01 & 3.88 & 3.78 & 3.67 \\
\hline $\mathrm{P}_{17}$ & $\begin{array}{c}\text { Short distance location between bus } \\
\text { e-ticket counter and bus gate }\end{array}$ & 3.71 & 3.57 & 3.68 & 3.59 \\
\hline $\mathrm{P}_{18}$ & Ease to find out bus e-ticket location & 3.95 & 3.84 & 3.83 & 3.77 \\
\hline
\end{tabular}




\begin{tabular}{|c|c|c|c|c|c|}
\hline \multirow{2}{*}{ Component } & \multirow{2}{*}{ E-ticket questionnaire } & \multicolumn{2}{|c|}{$\begin{array}{c}\text { Trans-Sarbagita Buses } \\
\text { Denpasar, Bali }\end{array}$} & \multicolumn{2}{|c|}{$\begin{array}{c}\text { Surabaya-Yogyakarta } \\
\text { Buses, Surabaya, East } \\
\text { Java }\end{array}$} \\
\cline { 3 - 6 } & \multicolumn{2}{|c|}{$\begin{array}{c}\text { Level of } \\
\text { Necessity }\end{array}$} & $\begin{array}{c}\text { Level of } \\
\text { Priority }\end{array}$ & $\begin{array}{c}\text { Level of } \\
\text { Necessity }\end{array}$ & $\begin{array}{c}\text { Level of } \\
\text { Priority }\end{array}$ \\
\hline $\mathrm{P}_{19}$ & Quality of bus e-ticket card & 3.84 & 3.65 & 3.76 & 3.67 \\
\hline $\mathrm{P}_{20}$ & $\begin{array}{c}\text { Ease of complaining about bus e- } \\
\text { ticket service }\end{array}$ & 4.01 & 3.96 & 3.81 & 3.70 \\
\hline
\end{tabular}

Table 2. Level of necessity and level of priority of ICT implementation at major bus terminal.

\begin{tabular}{|c|c|c|c|c|c|}
\hline \multirow{2}{*}{ Component } & \multirow{2}{*}{$\begin{array}{l}\text { ICT implementation } \\
\text { at major bus terminal } \\
\text { questionnaire }\end{array}$} & \multicolumn{2}{|c|}{$\begin{array}{l}\text { Mengwi Bus Terminal, } \\
\text { Denpasar, Bali }\end{array}$} & \multicolumn{2}{|c|}{$\begin{array}{c}\text { Purabaya Bus Terminal, } \\
\text { Surabaya, East Java }\end{array}$} \\
\hline & & $\begin{array}{l}\text { Level of } \\
\text { Necessity }\end{array}$ & $\begin{array}{l}\text { Level of } \\
\text { Priority }\end{array}$ & $\begin{array}{l}\text { Level of } \\
\text { Necessity }\end{array}$ & $\begin{array}{l}\text { Level of } \\
\text { Priority }\end{array}$ \\
\hline $\mathrm{P}_{1}$ & $\begin{array}{l}\text { Availability of bus name, schedule } \\
\text { and route in the terminal }\end{array}$ & 4.21 & 4.26 & 4.23 & 3.67 \\
\hline $\mathrm{P}_{2}$ & $\begin{array}{l}\text { Availability of e-ticketing in the } \\
\text { terminal }\end{array}$ & 3.80 & 3.76 & 3.74 & 3.74 \\
\hline $\mathrm{P}_{3}$ & $\begin{array}{l}\text { Availability of e-ticketing through } \\
\text { website in the terminal }\end{array}$ & 3.44 & 3.36 & 3.88 & 3.69 \\
\hline $\mathrm{P}_{4}$ & $\begin{array}{c}\text { Availability of self-ticketing in the } \\
\text { terminal }\end{array}$ & 3.72 & 3.63 & 3.86 & 3.71 \\
\hline $\mathrm{P}_{5}$ & $\begin{array}{l}\text { Ease of getting bus name, schedule } \\
\text { and route in the terminal }\end{array}$ & 4.21 & 4.12 & 3.85 & 3.75 \\
\hline $\mathrm{P}_{6}$ & $\begin{array}{l}\text { Ease of getting e-ticketing } \\
\text { information in the terminal }\end{array}$ & 3.82 & 3.79 & 3.86 & 3.73 \\
\hline $\mathrm{P}_{7}$ & $\begin{array}{l}\text { Ease of getting e-ticketing website in } \\
\text { the terminal }\end{array}$ & 3.51 & 3.40 & 3.85 & 3.72 \\
\hline $\mathrm{P}_{8}$ & $\begin{array}{l}\text { Ease of getting self-ticketing } \\
\text { information in the terminal }\end{array}$ & 3.79 & 3.68 & 3.85 & 3.79 \\
\hline $\mathrm{P}_{9}$ & $\begin{array}{l}\text { Availability of real time bus location } \\
\text { information in terminal }\end{array}$ & 3.76 & 3.60 & 3.88 & 3.77 \\
\hline $\mathrm{P}_{10}$ & $\begin{array}{l}\text { Availability of information in the } \\
\text { terminal using loud speaker }\end{array}$ & 3.75 & 3.71 & 3.92 & 3.81 \\
\hline $\mathrm{P}_{11}$ & $\begin{array}{l}\text { Availability of bus delay time } \\
\text { information using loud speaker }\end{array}$ & 4.01 & 4.07 & 3.79 & 3.83 \\
\hline $\mathrm{P}_{12}$ & $\begin{array}{l}\text { Availability of bus delay time on } \\
\text { information board }\end{array}$ & 4.13 & 4.13 & 3.92 & 3.85 \\
\hline $\mathrm{P}_{13}$ & Availability of terminal map & 4.00 & 3.96 & 3.78 & 3.64 \\
\hline $\mathrm{P}_{14}$ & Availability of wi-fi and hot spot & 3.65 & 3.54 & 3.86 & 3.84 \\
\hline $\mathrm{P}_{15}$ & $\begin{array}{l}\text { Availability of complaint service by } \\
\text { mobile phone application, website }\end{array}$ & 3.79 & 3.77 & 3.89 & 3.74 \\
\hline
\end{tabular}


Moreover, the second primary data are from a questionnaire to 566 passengers as respondents regarding ICT implementation necessity and priority at Mengwi major bus terminal in Denpasar Bali and Purabaya major bus terminal in Surabaya, East Java, by surveyors. The questionnaire and the average value are presented in Table 2. Likert scale with value 1 up to value 5 is used in the questionnaire.

\subsection{Analysis data regarding bus e-ticket and ICT implementation}

The method used in the analysis is Important Performance Analysis, which is described in a Cartesian Diagram. The Cartesian Diagram in Fig. 2 describes the relationship between the level of necessity and of the level of priority of bus e-ticket service and the Cartesian Diagram in Fig. 3 describes the relationship between the level of necessity and of the level of priority of ICT implementation at the major bus terminal.
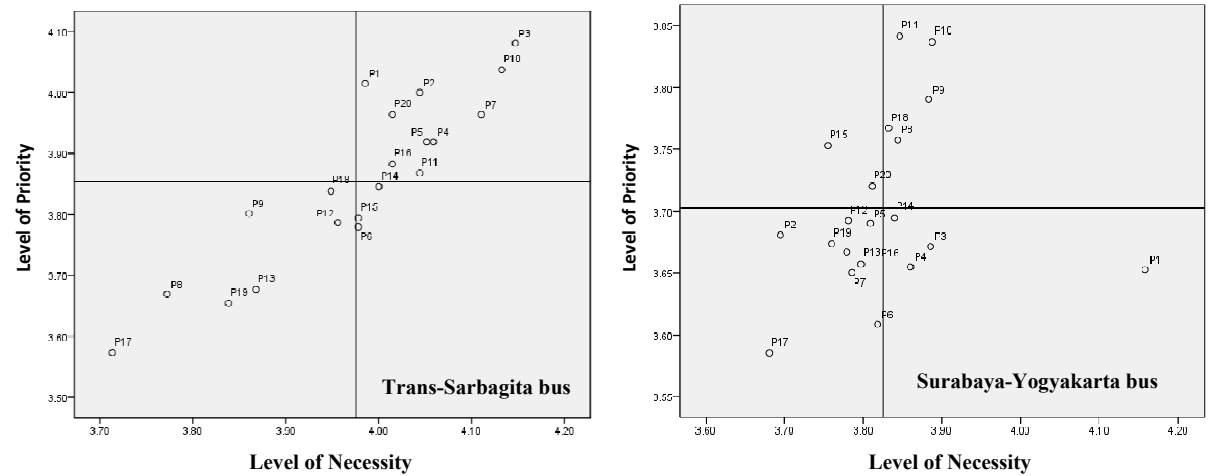

Fig.2. Relationship between level of necessity and level of priority of bus e-ticket service on TransSarbagita buses in Denpasar, Bali, and on Surabaya-Yogyakarta buses in Surabaya, East Java.
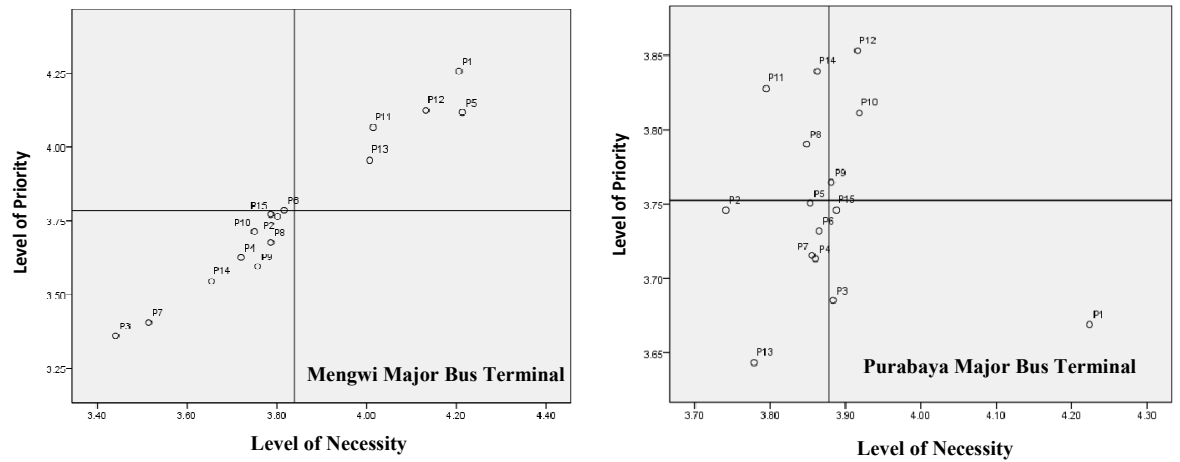

Fig.3. Relationship between level of necessity and level of priority of ICT implementation at Mengwi major bus terminal in Denpasar, Bali, and on Purabaya major bus terminal in Surabaya, East Java.

\section{Stages of ICT implementation}

The stages of ICT implementation are recommended based on field data and analysis provided earlier and based on the existing condition of the buses and major bus terminals. The stages are recommended to be applied with practical achievement. 


\subsection{Stage 1 of ICT Implementation on buses and at bus terminals}

Stage 1 to be applied in practice is good maintenance of the existing basic ICT which has been implemented daily based on interview results with major terminal authorities, i.e., bus e-ticketing and CCTV surveillance in the major bus terminal. By maintaining the basic ICT, the quality of overall service to passengers, i.e., easiness, fastness, and convenience, will, therefore, be improved.

\subsection{Stage 2 of ICT Implementation on buses and at bus terminals}

Stage 2 is an improvement of the ability of major bus terminal operators and dissemination of existing and future basic ICT facilities, such as wi-fi and hot spot in the bus terminal, to society, especially bus passengers. This stage is essential for efficient and effective daily operation can be done in practice and delivers relevant information to the passenger. The information is, for example, bus e-ticketing, bus schedule, bus route, bus tariff, and bus delay time. This information will ensure passenger satisfaction in arranging and completing their trip.

\subsection{Stage 3 of ICT Implementation on buses and at bus terminals}

Stage 3 requires great effort by the terminal authority to implement as early as possible the bus e-ticket based on passengers' opinions of the biggest necessity and priority as presented in Table 1 and in Fig. 2 (the highest values), i.e. ease of getting bus e-ticket information service (P1), availability of bus operational schedule information while buying a bus e-ticket (P2), availability of bus route information while buying a bus e-ticket (P3), ease of getting bus e-ticket service access (P4), consistency of bus e-ticket service time (P5), security of bus e-ticket counter (P7), affordability of bus e-ticket (P10), ease of bus eticket top up (P11), convenience of passengers while queued to buy bus e-ticket (P16), ease to find out bus e-ticket location (P18), and ease to complain about bus e-ticket service (P20).

\subsection{Stage 4 of ICT Implementation on buses and at bus terminals}

Stage 4 requires great effort by terminal authority to implement as early as possible the ICT based on passengers' opinions of the biggest necessity and priority as presented in Table 2 and Fig. 3 (the highest values), i.e. availability of information regarding name, schedule and route of bus in the terminal (P1), ease of getting information regarding name, schedule and route of bus in the terminal (P5). availability of information in the terminal regarding real-time bus location (P9), availability of information in the terminal using loudspeaker (P10), availability of information in the terminal regarding bus delay time using loudspeaker (P11), availability of information in the terminal regarding bus delay time using information board (P12), and availability of information in the terminal regarding terminal map and layout (P13).

\subsection{Stage 5 of ICT Implementation on buses and at bus terminals}

Stage 5 is the implementation of other advanced ICT that can be implemented on buses and at major bus terminals in the future, as presented in Table 3, with some requirements to ensure that the ICT will be applied. The requirements are, for example, financial support, great effort and the ability of officers from local government and national government, as well as industry, all consistently and continuously. 
Table 3. Stage 5 of advanced ICT implementation on buses and at major bus terminals.

\begin{tabular}{|c|l|}
\hline $\begin{array}{c}\text { Advanced ICT } \\
\text { technology }\end{array}$ & \multicolumn{1}{c|}{ Explanation } \\
\hline $\begin{array}{c}\text { Automatic bus } \\
\text { location system }\end{array}$ & $\begin{array}{l}\text { It will assist the terminal authority regarding real time bus } \\
\text { location, bus delay time, bus arrival time and bus } \\
\text { breakdown }\end{array}$ \\
\hline $\begin{array}{c}\text { Real time passenger } \\
\text { information system }\end{array}$ & $\begin{array}{l}\text { It informs passengers regarding real time bus schedule, } \\
\text { bus route, bus delay time in bus terminal and at bus stops, } \\
\text { and parking information }\end{array}$ \\
\hline $\begin{array}{c}\text { Advanced bus } \\
\text { ticketing system }\end{array}$ & $\begin{array}{l}\text { It benefits passengers to arrange their bus trip, reduces } \\
\text { time consuming and inconvenience while changing bus } \\
\text { schedule, bus route and refund of bus fare using } \\
\text { application on a mobile phone }\end{array}$ \\
\hline
\end{tabular}

\section{Conclusions}

ICT implementation on buses and at major bus terminals in large cities in Indonesia towards sustainable transportation is crucial to improve service quality; however, it is still at the beginning level. This condition means implementation of ICT cannot be applied in a short time but needs stages. The stages that can be done in practice start with the maintenance and dissemination of existing basic ICT, a serious effort to implement ICT based on necessity and priority of passengers, and then the implementation of advanced ICT in the future by the local and national government, consistently and continuously.

Thank you very much to Direktorat Riset dan Pengabdian kepada Masyarakat, Direktorat Jenderal Penguatan Riset dan Pengembangan, Ministry of Research, Technology, and Higher Education, Republic of Indonesia.

\section{References}

1. A.C. Sutandi, W. Santosa, N.A. Solossa, Proceedings of EASTS 201711 (2017)

2. A.C. Sutandi, Proc. of Conference of the Asia-Pacific Weeks Berlin (2016)

3. J. King. How transportation technologies will change everything. Available at: http://www.govtech.com/transportation/How-Transportation-Technologies-WillChange-Everything-.html (2014)

4. $\quad$ K.V.R. Shankar, Int. J. of Earth Sci. and Eng. 4 (2011)

5. W.R. Black, Sustainable transportation, problems and solutions (Guilford Press, New York, 2010)

6. A.C. Sutandi, Advanced traffic control systems, performance evaluation in a developing country (LAP LAMBERT Academic Publishing, Saarbrucken, 2010)

7. J. Brummond, M. Chowdhury, R. Fries, Transportation infrastructure security, utilizing intelligent transportation systems (Jhon Wiley \& Son, New York, 2009)

8. C. Bragdon, Transportation security (Butterworth-Heinemann, Oxford, 2008)

9. G.H. Brundtland, Our common feature (United Nations World Commission on Environment and Development, Oslo, 1987) 
10. K.C. Sinha, L.F. Cohn, C.T. Hendrickson, Y. Stephanedes, ASCE J. of Transportation Eng. 114, 4 (1988)

11. P. Blythe, T. Rackliff, R. Holland, J. Mageean, J. of Advanced Transp. 34, 3 (2000)

12. P. Vasudevan, P. Mulukutla, Bus karo 2.0 - Case studies from India. Available at: https://wricitieshub.org/online-publications/bus-karo-20-\%E2\%80\%93-case-studiesindia (2014)

13. Menteri Perhubungan Republik Indonesia. Peraturan Menteri Perhubungan Republik Indonesia Nomor 40 Tahun 2015 tentang Standar Pelayanan Penyelenggaraan Terminal Penumpang Angkutan Jalan (Menteri Perhubungan Republik Indonesia, Jakarta, 2015)

14. Menteri Perhubungan Republik Indonesia. Peraturan Menteri Perhubungan Republik Indonesia Nomor 132 Tahun 2015 tentang Penyelenggaraan Terminal Penumpang Angkutan Jalan (Menteri Perhubungan Republik Indonesia, Jakarta, 2015)

15. Menteri Perhubungan Republik Indonesia. Peraturan Menteri Perhubungan Republik Indonesia Nomor 25 Tahun 2009 tentang Pendelegasian Kewenangan Menteri Perhubungan Kepada Direktur Jenderal Perhubungan Udara di Bidang Penerbangan (Menteri Perhubungan Republik Indonesia, Jakarta, 2009)

16. R.L. Ott, M. Longnecker, An introduction to statistical methods and data analysis (Brooks/Cole CENGAGE Learning, Boston, 2010) 